\title{
BRASIL: A LEITURA PÓS-CONSTITUIÇÃO DO BROCARDO IN DUBIO PRO SOCIETATE. ANÁLISE DE PRECEDENTES QUE AFASTARAM SUA APLICAÇÃO
}

\author{
Benedicto De Souza Mello Neto ${ }^{1}$ \\ Diego Prezzi Santos ${ }^{2}$ \\ Universidade Estadual de Londrina, Brasil
}

http://dx.doi.org/10.5209/rev_NOMA.2012.41783

\begin{abstract}
Resumo: O presente artigo científico buscou esclarecer sobre a nova compreensão que o Superior Tribunal de Justiça tem, em alguns de seus julgados, sobre o In dubio pro societate. Demonstrou-se que este brocador tornou-se, por uma questão de conveniência, uma espécie de princípio do direito mesmo não tendo qualquer suporte legal. Houve uma ampliação de seus efeitos e tal fenônemo é investigado neste estudo. Na seqüência se apresento o entendimento trazidos pela doutrina processual penal e por alguns tribunais sobre a aplicação deste brocardo em seus âmbitos de incidência, inovando em relação ao exercício de mera repetição que havia anteriormente.
\end{abstract}

Palavras-chave: in dubio pro societate, princípio, fundamento, origem, entedimento

\section{New reading of the principle in dubio pro societate: analysis of sentences violating the principle}

\begin{abstract}
This research sought clarification on the new understanding of the High Court of Justice in some of their decisions on the pro dubio In Societat. It showed that the brocadorbecame, for reasons of convenience, a kind of principle of the law, while having no legal support. There was an expansion of this phenomenon is the effect and is investigated in this study. There was then the current understanding of the doctrine of criminal procedure and some courts in applying this Brocardus in their areas of expertise, innovation in the mere exercise of repeating that he had previously.
\end{abstract}

Keywords: in dubio pro societate, beginning, foundation, origin, boring

SUMÁRIO: Introdução; Desenvolvimento; 1 In dubio pro societate, conceito e extensão; 2 A aplicação do brocardo nos processos do júri; 3 A expansão de efeitos para o recebimento da denúncia; $4 \mathrm{Da}$ falta de fundamento legal para o famigerado termo e da sabotagem constitucional causada por seu uso; $5 \mathrm{Da}$ reação dos Tribunais em busca de adequação do processo com a Dignidade; Concluões, Bibliografia.

\footnotetext{
${ }^{1}$ Mestre em Direito supraindividual (Universidade Estadual de Maringá). Professor de direito penal e processo penal na graduação e especialização da Universidade Estadual de Londrina (UEL) e na Faculdade Catuaí. Advogado em Londrina, Paraná.

2 Mestrando em Direitos da Personalidade pelo Centro Universitário de Maringá. Pósgraduando em Direito e Processo Penal pela Universidade Estadual de Londrina. Graduado pela Universidade Estadual de Londrina. Professor de Direito Penal II, Direito Penal V e Direito Penal VI na Faculdade Catuaí em Cambe, Paraná. Advogado em Londrina, Paraná.
} 


\section{INTRODUÇÃO}

O presente estudo se propõs a investigar a origem do brocardo In dubio pro societate, verificando, no primeiro tópico, seu significado e sua extensão no processo penal brasileiro, segundo a jurisprudência do Supremo Tribunal Federal e do Superior Tribunal de Justiça.

No tópico seguinte, procurou-se identificar o tipo de processo em que tal brocardo é mais aplicado e as razões disso, também se tratou de expor, na seqüência, que o alcance do in dubio pro societate se ampliou com o passar do tempo e a jurisprudência repercutiu esta expansão em muitos julgados.

Isso porque no momento de se receber a denúncia houve utilização da malversada expressão.

Analisar-se-a, após, a natureza jurídica de tal postulado, demonstrando que não existe fundamento legal no Ordenamento Jurídico nacional ou mesmo nos tratados internacionais que justifiquem sua aplicação no Brasil.

Será verificado o posicionamento da doutrina e foram pincaçados os autores que não concordam com o brocardo e apresentadas suas razões.

Com uma busca minuciosa na jurisprudência dos tribunais de justiça e também nos julgados dos tribunais superiores, foram trazidos os resultados ao presente trabalho na intenção de demonstrar que, embora ainda bastante usual, o aforismo encontrou óbices em sua aplicação no Superior Tribunal de Justiça e em alguns tribunais de justiça.

Consoante tais julgados, a análise será para comprovar os fundamentos técnicos acertados e alinhados com o que determina a constituição federal.

No derradeiro tópico, apresenta-se a conclusão feita sobre a necessidade de, como já iniciada pelos tribunais, realizar uma revisão sobre a aplicação deste brocardo.

\section{IN DUBIO PRO SOCIETATE, CONCEITO E EXTENSÃO}

No direito brasileiro é recorrente o uso de brocardos e expressões em obras, pareceres e julgados sem que haja uma devida atenção a origem e a natureza jurídicas destas palavras. O "pas de nullité sans grief", o "in dubio pro reo" e, principalmente, o "in dubio pro societate" são regularmente lidos e aplicados no mundo jurídicos sem uma análise detida, é o perigoso exercício de repetição. 
O in dubio pro societate, objeto desse trabalho, é ainda mais usual que os demais, pois, além de se aplicar aos casos sobre os quais, inicialmente, incidia, houve uma expansão para outras fases do processo.

E o que é esta expressão e qual sua função no direito?

A resposta é encontrada com acerta na pesquisa feita por Marcio Ferreira Rodrigues Pereira:

O "princípio" do in dubio pro societate é costumeiramente invocado por vasto setor comunidade jurídica em, pelo menos, dois momentos específicos da persecutio criminis: no ato de recebimento da inicial penal e na fase de pronúncia no procedimento do júri.

Tanto em um como em outro momento, uma das idéias fundamentais representadas pelo referido "princípio" é a seguinte: a dúvida quanto à autoria da infração penal que, normalmente, milita em prol do réu (in dubio pro reo), nessas situações especiais, resolve-se em favor da sociedade (da acusação, portanto). ${ }^{3}$

Interessante notar o uso de aspas na palavra 'princípio' o que já denota a desconfiança sobre a natureza de tal expressão.

O autor faz uma leitura sobre as funções do preceito que, nas duas situações processuais apresentadas, faz incidir uma idéia de dúvida em desfavor do processado.

Para se entender toda a extensão do in dubio pro societate é necessário vislumbrar o que ele é. Numa análisa das mais detidas, Sergio Pitombo apresentou considerações importantes que culminam com o seguinte:

O tema é o mero aforismo - não um princípio de Direito - in dubio pro societate, como eventual fundamento da decisão interlocutória de pronúncia, emergente no procedimento especial de Júri (art. 408, caput, do Cód. de Proc. Penal). ${ }^{4}$

Expressa o autor não é principio algum e sim um simples provérbio que - assim como muitos outros responsáveis por expressar idéias difundidas na sociedade, como "melhor começar a noite que não começar", "meia verdade é uma mentira inteira" - não expressa conteúdo jurídico sedimentado.

O in dubio pro societate é, na verdade, um provérbio que foi levado ao sistema jurídico. Quanto ao seu conteúdo, o mesmo Sergio Pitombo expressa à significação de um preceito importante, esse sim princípio construído ao longo da história jurídica, que é o In dubio pro reo:

In dubio pro reo significa: "na dúvida, a favor do réu"; ou, "na dúvida, solucionase em favor do acusado". Menciona-se, ainda, o "benefício da dúvida", ao tratar-se de questão de fato. Benefício é favor, mercê, ou graça. O juiz não distribui favores, mas, justiça. Emerge dicção pouco feliz ${ }^{5}$.

\footnotetext{
${ }^{3}$ PEREIRA, Márcio Ferreira Rodrigues. Acusar ou não acusar? Eis a questão... . O "in dubio pro societate" como forma perversa de lidar com a dúvida no processo penal brasileiro.. Jus Navigandi, Teresina, ano 16, n. 2775, 5 fev. 2011. Disponível em: <http://jus.uol.com.br/revista/texto/18424>. Acesso em: 18 jul. 2011.

4 PITOMBO, Sergio. Pronuncia $e$ o in dubio pro societate. Disponível em http://www.sergio.pitombo.nom.br/files/word/in_dubio.doc. Acesso em 19/07/2011.

5 PITOMBO, Sergio. Pronuncia $e^{-}$in dubio pro societate. Disponível em http://www.sergio.pitombo.nom.br/files/word/in_dubio.doc. Acesso em 19/07/2011.
} 
Com os dizeres do doutrinador a conclusão sobre o in dubio pro societate é simples, porquanto é antagônico ao que foi por ele escrito. $O$ in dubio pro societate é: na dúvida, a favor da sociedade, na dúvida, soluciona-se a favor da sociedade. Embrenhado no conceito de "favor da sociedade" está a obviedade de que se decide contra o cidadão acusado em processo criminal. Importante salientar que a decisão não é, então, a favor da sociedade e sim contra o acusado, a expressão mais acertada seria in dubio contra reo.

Isso porque não há que se confundir o interesse da socidade com o do acusador público ou privado, diferente do in dubio pro reo que diz respeito ao interesse do cidadão acusado.

Consoante origem, aponta-se Roma como o berço no qual foi bem nascido o in dubio pro reo:

No Direito romano, encontram-se expressões análogas: in dubio quod minimum est sequimur (D., XXVIII, IV, 3), "na dúvida seguimos aquilo que é mínimo"; e semper in dubiis benigniora proeferenda sunt (D., L, XVII, 56), "em caso de dúvida sempre se deve preferir o mais benigno". Não se acha, porém, a frase em comento, nas fontes romanas clássicas. Assegura-se que aparece no baixo império romano e por influência do cristianismo; mediante tardia interpolação em sentença de Paulo. Note-se que a cláusula lançou-se em matéria referente à manumissão do escravo comum. A passagem para o processo penal, possivelmente, sucedeu no século XIX ${ }^{6}$.

Logo, fora uma construção amparada em entendimentos históricos construídos para separar a injustiça fria e doente da justiça nos casos concretos quando os responsáveis por acusar não conseguem produzir a prova para alterar o status libertatis de um cidadão.

Já o In dubio pro societate, diferentemente, não apresenta uma raiz histórica ou mesmo um aporte jurídico amplo e bem fundamentado. Eis a lição doutrinária:

É fácil, na seqüência, perceber que a expressão in dubio pro societate não exibe o menor sentido técnico. Em tema de direito probatório, afirmar-se: "na dúvida, em favor da sociedade" consiste em absurdo lógico-jurídico. Veja-se: em face da contingente dúvida, sem remédio no tocante à prova - ou na imaginada incerteza - decide-se em prol da sociedade. Dizendo de outro modo: se o acusador não conseguiu comprovar o fato, constitutivo do direito afirmado, posto que conflitante despontou a prova; então, se soluciona a seu favor, por absurdo. Ainda, porque não provou ele o alegado, em face do acusado, deve decidir-se contra o último. Ao talante, por mercê judicial o vencido vence, a pretexto de que se favorece a sociedade: in dubio contra reum. Só o exagerado positivismo jurídico quase desaparecido - pode tolerar o sério malentendido. O fenômeno processual mantém-se: a acusação não suportou 0 onus probandi. Subjacente à assertiva in dubio pro societate acha-se o vedado

${ }^{6}$ PITOMBO, Sergio. Pronuncia e 0 in dubio pro societate. Disponível em http://www.sergio.pitombo.nom.br/files/word/in_dubio.doc. Acesso em 19/07/2011. 
procedimento de ofício e a quebra da denominada presunção de inocência (arts. $5^{\circ}$, inc. LVII e inc. I, da Const. da República) ${ }^{7}$.

Roberto de Ruggiero exemplifica como foi a criação de diversos desses aforismos jurídicos e como ocorreu o processo de "internalização" destes nos ordenamentos jurídicos, apontando, ainda, a crítica a ser feita com o uso de tais expressões:

1) Na escolástica antiga e na prática do povo foi-se formando um pouco no ar uma série de brocardos ou aforismos jurídicos,. que são repetidos pelos práticos a todo o momento e retidos como expressões de regras fíxas e princípios absolutos. Toda a teoria da interpretação se resume assim, para alguns, no uso dessas máximas, arrancadas freqüentemente à lógica e a maior parte das vêzes adotadas absolutamente fora de propósito. Soam como outros tantos provérbios da sapiência jurídica (por exemplo: 'ubi eadem legis ratio, ibi eadem dispositio' - cessante ratione legis cessat et ipsa lex - 'ubi lex non distinguit, nec nos distinguere debemus' - inclusio unius exclusio alterius' in eo quod plus est semper inest et minus' etc.), e são por vezes o mais perigoso instrumento nas mãos do juiz, desde que seja pouco experimentado na difícil arte de interpretar. Têm na verdade a aparência de princípios gerais e absolutos e, pelo contrário, não há um único que não seja falso como máxima geral: parecem as mais das vezes contraditórios e antitéticos, visto que em face de um, que afirma dada regra, é sempre possivel encontrar um segundo que contenha regra oposta; tem cada um dêles um campo de aplicação com limites próprios, fora dos quais vigora a regra oposta, mas não exprimem quais sejam êsses limites. Ora um grande número dos erros cometidos na aplicação dos textos de lei, tem a sua causa direta e imediata no abuso que todos os dias os juizes e advogados fazem dêstes aforismos que, como foi dito, são todos eles falsos na sua generalidade ${ }^{8}$.

O famigerado ditado popular do in dubio pro societate não escapa à mesma crítica. Seguindo nas lições de Aury Lopes Jr, a promotora Ana Cláudia Bastos de Pinho expõe o risco inerente a uma utilização descompromissada com maiores análises:

Acusações injustificadas, com base no in dubio pro societate, possuem um efeito criminógeno espetacular. Além de submeter 0 imputado ao constrangimento natural do processo penal, ainda o expõe a outras conseqüências mais drásticas, verdadeiras penas processuais, como v.g., as prisões cautelares e os assédios da mídia sensacionalista que se alimenta de escândalos e muitas vezes sequer espera a formalização da acusação, promovendo uma execração pública do investigado antes mesmo de existir processo.

É interessante notar que qualquer pessoa pode ter contra si ajuizada uma ação de natureza civil, tributária, trabalhista, sem que isso lhe cause algum mal ou a exponha a qualquer situação vexatória. Tal não ocorre com o processo penal,

\footnotetext{
7 PITOMBO, Sergio. Pronuncia e o in dubio pro societate. Disponível em http://www.sergio.pitombo.nom.br/files/word/in_dubio.doc. Acesso em 19/07/2011.

${ }^{8}$ RUGGIERO, Roberto de. Instituições de Direito Civil; Introdução e Parte Geral", tradução Ary dos Santos, 3" ed., revista e adaptada por Antônio Chaves e Fábio Maria de Mattia, São Paulo: Saraiva, 1971, v. I, § 17, p. 119-20
} 
que rotula e estigmatiza. É o que a Criminologia moderna chama de labeling approach (teoria do etiquetamento). Em razão de acusações sem justa causa, o indivíduo sofre todas as agruras do processo penal, todas as humilhações e, não raro, corre o risco de ser segregado provisoriamente para, após encerrada a instrução, vir a ser absolvido por falta de provas. Essa é a conseqüência perniciosa da aplicação do in dubio pro societate ${ }^{9}$.

Decidir-se, quando da incerteza, contra o réu apresenta o nefasto efeito de conduzir o acusado ao procedimento criminal - com suas mazelas inerentes e, cada vez mais exploradas pela mídia - sem que o trabalho policial ou até mesmo ministerial tenha cumprido bem sua missão de produção probatória.

É um brocardo, portanto, criado pela indiferença com a dignidade e com o descumprimento de uma ensinamento de efetividade que vincula(ria) a atividade investigativa.

Sua extensão é medida, nos processos apenas quando paira a incerteza ocasionada pelo fato de que não se produziu informação inquisitorial suficiente - quando incide o brocardo no recebimento da denúncia - ou prova suficiente quando, sob o contraditório, a acusação não demonstou que sua tese poderia, efetivamente, levar o acusado a condenação criminal nos crimes dolosos contra a vida.

A conveniência é o fundamento do in dubio pro societate.

\section{A APLICAÇÃO DO BROCARDO NOS PROCESSOS DO JÚRI}

No Brasil foi convencionado que o procedimento do júri, que julga crimes dolosos contra a vida, em regra com penas bastante altas, deve ser regido pelo pela dúvida contra o acusado.

A pena mínima para processos julgados no procedimento do júri é de 01 (um) ano nos crimes de instigação ou induzimento ao suicídio (art. 122 do Código Penal) em sua forma tentada e de 02 (dois) anos para a conduta tipificada como infanticídio (art. 123 do Código Penal) e figura consumada do art. 122 do Código Penal.

Quanto à pena máxima possível, se verifica a do homicídio qualificado (art. 121, §2 e seus incisos do Código Penal) de até 30 (trinta) anos.

Questão importante é que tais delitos dizem respeito ao bem jurídico de maior valor jurídico, que é a vida humana e, de conseqüência, os processos resultam em penas mais graves àqueles que são condenados pelo conselho de sentença, além da pecha de, em alguns casos, crime hediondo.

Outra importante situação é que o estigma de ser julgado e condenado pelos próprios pares é maior que a já gravosa condenação pelo juízo singular, pois, além de público e aberto, o sujeito que se senta no banco dos réus tem suas

\footnotetext{
${ }^{9} \mathrm{PINHO}$, Ana Cláudia Bastos de. In dubio pro societate $\mathrm{x}$ processo penal garantista. Disponível em http://alexandremoraisdarosa.blogspot.com/2009/06/puxada-de-orelha-merecida.html. Acesso em 15/07/2011.
} 
verdades e suas mentiras expostas ao público, como se sua intimidade não existisse ou não fosse importante.

Disso resultaria que haveria necessidade de uma maior preciso para se encaminhar alguém ao tribunal do júri. Não é o que pensa a jurisprudência.

Marcio Ferreira Rodrigues Pereira expõe o uso do in dubio contra reo para levar o acusado, na dúvida, para o plenário do júri:

No que concerne à decisão de pronúncia (art. 413 do CPP ${ }^{[04]}$ ), é também com muita freqüência que se invoca o aludido "princípio" do in dubio pro societate. As razões para a adoção do brocardo nesse momento decisório são as seguintes. Primeiro, diz-se que, em sede de decisão de pronúncia (assim como ocorre no recebimento da inicial penal), não se exige certeza da autoria do réu, mas, apenas, conforme sublinha o próprio art. 413 do CPP, indícios suficientes desta. Ademais, outro motivo dado pela tradicional doutrina para sustentar o in dubio pro societate na fase de pronúncia diz respeito à questão do juiz natural da causa no procedimento do júri. Explica-se. Como no júri o juiz natural da causa são os jurados (e não o magistrado togado), eventual dúvida a respeito da admissibilidade da acusação deve ser resolvida pelo tribunal popular. É comum, pois, encontrar, em diversos manuais de processo penal e decisões jurisprudenciais, a seguinte frase: "na dúvida, deve o juiz pronunciar o acusado" ${ }^{10}$.

A dúvida contra o réu neste procedimento é acionada quando, após a primeira fase de instrução, o juízo decide sobre encaminhar o acusado a júri ou não com o uso da decisão de pronúncia. Na elaboração da decisão de pronúncia, segundo o senso comum, aplica-se $o$ in dubio pro societate e afasta-se 0 in dubio pro reo.

A jurisprudência aceita com passividade esta situação, como se pode verificar no Superior Tribunal de Justiça:

AGRAVO REGIMENTAL NO AGRAVO DE INSTRUMENTO. PENAL. CRIME DE TENTATIVA DE HOMICÍDIO. SUPOSTA VIOLAÇÃO AO ART. 155 DO CÓDIGO DE PROCESSO PENAL. INEXISTÊNCIA. POSSIBILIDADE DE PROVAS COLHIDAS NO INQUÉRITO POLICIAL AUXILIAREM NA FUNDAMENTAÇÃO DA DECISÃO DE PRONÚNCIA. EXAME DE MATÉRIA FÁTICO-PROBATÓRIA. DESCABIMENTO. INCIDÊNCIA DA SÚMULA No 7 DESTE TRIBUNAL. ALEGADA DIVERGÊNCIA JURISPRUDENCIAL. FALTA DE SIMILITUDE FÁTICA ENTRE OS JULGADOS RECORRIDO E PARADIGMA. AGRAVO DESPROVIDO. 1. A teor do disposto no art. 408, caput, do Código de Processo Penal, na redação conferida pela Lei $n^{0}$ 5.941, de 22/11/1973, não se faz necessário, na pronúncia, um juízo de certeza a respeito da autoria do crime, mas que o Juiz se convença da existência do delito e de indícios suficientes de que o réu seja o seu autor, por se aplicar, nessa fase, o princípio do in dubio pro societate. Precedente do Supremo

\footnotetext{
${ }^{10}$ PEREIRA, Márcio Ferreira Rodrigues. Acusar ou não acusar? Eis a questão... . O "in dubio pro societate" como forma perversa de lidar com a dúvida no processo penal brasileiro.. Jus Navigandi, Teresina, ano 16, n. 2775, 5 fev. 2011. Disponível em: <http://jus.uol.com.br/revista/texto/18424>. Acesso em: 18 jul. 2011.
} 
Tribunal Federal. 2. Esta Corte Superior de Justiça já decidiu no sentido da possibilidade de a pronúncia ser fundamentada em provas colhidas no inquérito policial e que não foram rechaçadas na instrução contraditória. 3. A pretensão de impronúncia, por ausência de indícios suficientes de autoria, esbarra no óbice contido no verbete sumular $n^{\circ} 7$ deste Superior Tribunal de Justiça. 4. Quanto à arguida divergência jurisprudencial, não há similitude fática entre os julgados. Com efeito, o aresto paradigma consignou que a decisão de pronúncia não foi minimamente fundamentada, limitando-se a transcrever a denúncia. O decisum hostilizado, por outro lado, fundamentou a pronúncia do Réu após percuciente análise das provas inquisitoriais e judiciais produzidas, não se limitando, por certo, aos termos em que foi relatada a inicial acusatória. 5. Agravo regimental desprovido. (STJ; AgRg-Ag 1.304.510; Proc. 2010/0081182-2; DF; Quinta Turma; Rela Mina Laurita Hilário Vaz; Julg. 19/05/2011; DJE 07/06/2011)

A Corte Constitucional não difere em entendimento, aplicando o ditado popular quando da pronúncia:

PENAL. PROCESSUAL PENAL. PROCEDIMENTO DOS CRIMES DA $\begin{array}{lll}\text { COMPETENNCIA DO JURI. } & \text { DO ICIUM }\end{array}$ ACUSATIONIS. IN DUBIO PRO SOCIETATE. SENTENÇA DE PRONÚNCIA. INSTRUÇÃO PROBATÓRIA. JUIIZO COMPETENTE PARA JULGAR OS CRIMES DOLOSOS CONTRA A VIDA. PRESUNÇÃO DE INOCÊNCIA. PRECEDENTES DA SUPREMA CORTE. 1. No procedimento dos crimes de competência do Tribunal do Júri, a decisão judicial proferida ao fim da fase de instrução deve estar fundada no exame das provas presentes nos autos. 2. Para a prolação da sentença de pronúncia, não se exige um acervo probatório capaz de subsidiar um juízo de certeza a respeito da autoria do crime. Exige-se prova da materialidade do delito, mas basta, nos termos do artigo 408 do Código de Processo Penal, que haja indícios de sua autoria. 3. A aplicação do brocardo in dubio pro societate, pautada nesse juízo de probabilidade da autoria, destina-se, em última análise, a preservar a competência constitucionalmente reservada ao Tribunal do Júri. 4. Considerando, portanto, que a sentença de pronúncia submete a causa ao seu Juiz natural e pressupõe, necessariamente, a valoração dos elementos de prova dos autos, não há como sustentar que o aforismo in dubio pro societate consubstancie violação do princípio da presunção de inocência. 5. A ofensa que se alega aos artigos 50, incisos XXXV e LIV, e 93, inciso IX, da Constituição Federal (princípios da inafastabilidade da jurisdição, do devido processo legal e da motivação das decisões judiciais) se existisse, seria reflexa ou indireta e, por isso, não tem passagem no recurso extraordinário. 6. A alegação de que a prova testemunhal teria sido cooptada pela assistência da acusação esbarra na Súmula $n^{\circ}$ 279/STF. 7. Recurso extraordinário a que se nega provimento. (STF; RE 540.999-6; SP; Primeira Turma; Rel. Min. Menezes Direito; Julg. 22/04/2008; DJE 20/06/2008; Pág. 89)

Estas jurisprudências não são isoladas, são o que existe de majoritário nos tribunais superiores e também nos estaduais e federais. Na doutrina ainda é disseminado tal entendimento, conforme elucida Gustavo Henrique Righi Ivahy Badaró: 
Prevacele na doutrina o entendimento de que, se houver dúvida ao término da primeira fase, o acusado deve ser pronunciado, posto que a regra de julgamento seria o in dubio pro societate ${ }^{11}$.

Portanto, apenas não será pronunciado o acusado se estiver extremamente clara e definida a prova contrária ao interesse acusatório, "pois impera nessa fase o princípio 'in dubio pro societate"'12 "uma vez que há mero juízo de suspeita, não de certeza. O juiz verifica apenas se a acusação é viável, deixando o exame acurado para os jurados"13.

\section{A EXPANSÃO DE EFEITOS PARA O RECEBIMENTO DA DENÚNCIA}

Além da aplicação corriqueira da expressão escabrosa no momento da pronúncia, a caminhada do brocardo foi mais longa. Em sentido totalmente oposto ao que se poderia imaginar em um Estado com o valor-fundante Dignidade, arrombou-se o Devido Processo Legal ao permitir a denúncia quando for carente a Opinio delicti.

Marcio Ferreira Rodrigues Pereira faz a exposição sobre o tema:

No caso de recebimento da exordial acusatória, segundo dizem, justifica-se a fórmula in dubio pro societate, pois não se exige certeza da autoria da infração penal, bastando, ao revés, a presença de um mínimo de provas (suporte probatório mínimo ${ }^{[03]}$ ) para que se possa receber a peça acusatória. Ademais, consoante afirmam, não deve o juiz, nesse momento (recebimento da inicial), fazer incursão aprofundada nas provas, pois, agindo assim, estaria incorrendo em pré-julgamento do caso. Por esses motivos, é que sufragam que a dúvida deve ser resolvida pela admissibilidade da peça acusatória (ou seja: a favor da sociedade) ${ }^{14}$.

A questão é bastante interessante e merece ser vista sobre diversos aspectos.

Cumpre expor - adotando uma verticalização argumentativa - que a lesão mais grave decorrente de se processar da dúvida é àquela que se faz à Dignidade Humana.

Dispiciendo tratar sobre a mácula que um processo causa à pessoa, mais ainda o processo criminal. Não bastasse o etiquetamento, a angústia do acusado, da família, as despesas, a acusado sobre com a incerteza do que poderá lhe esperar por ocasião da sentença.

Ao se falar em credibilidade da Justiça, assunto em moda para prender, não se pode fugir do fato de que, ao se aceitar a acusação sem provas, se promove

\footnotetext{
${ }^{11}$ BADARÓ, Gustavo Henrique Righi Ivahy. Direito Processual Penal. Tomo II. $2^{\mathrm{a}}$ ed. Rio de Janeiro: Elsevier, 2009, p. 79.

${ }^{12}$ BONFIM, Eugênio Moungenot. Curso de Processo Penal. 5a ed. São Paulo: Saraiva, 2010.

${ }^{13}$ CAPEZ, Fernando. Curso de Processo Penal. $17^{\text {a }}$ ed. São Paulo: Saraiva, 2010, p. 637.

${ }^{14}$ PEREIRA, Márcio Ferreira Rodrigues. Acusar ou não acusar? Eis a questão... . O "in dubio pro societate" como forma perversa de lidar com a dúvida no processo penal brasileiro.. Jus Navigandi, Teresina, ano 16, n. 2775, 5 fev. 2011. Disponível em: <http://jus.uol.com.br/revista/texto/18424>. Acesso em: 18 jul. 2011.
} 
uma descrença no sistema. A denúncia genérica e com informações inquisitoriais não-conclusivos permite o descrédito na polícia, já que não realizou como deveria seu trabalho, permite o descrédito na acusação, que demonstrou falta de compromisso com a constituição, com a dignidade e com a sociedade, permite descrédito do julgador que avança sobre a imparcialidade e o maior descrédito é de o Estado não garante e não se preocupa com os direitos fundamentais, que são elemento diferenciador entre regime democrático e arbitrário.

Apesar dos ditados constitucionais, é reinante na jurisprudência, que no momento de se receber a denúncia a dúvida é desfavorável ao réu e favorável ao interesse da acusação.

Os tribunais superiores tem este entendimento como predominante, conforme se verifica:

CONFLITO DE COMPETÊNCIA. PENAL. HOMICÍDIO, NA FORMA TENTADA, PRATICADO POR MILITAR CONTRA CIVIL. INQUÉRITO POLICIAL. NECESSIDADE DE EXAME DETALHADO E CUIDADOSO DO CONJUNTO PROBATÓRIO. PRINCÍPIO IN DUBIO PRO SOCIETATE. COMPETÊNCIA DA JUSTIÇA COMUM. 1. A presença de dolo, direito ou eventual, na conduta do agente só pode ser acolhida na fase inquisitorial quando se apresentar de forma inequívoca e sem necessidade de exame aprofundado de provas, eis que neste momento pré-processual prevalece 0 princípio do in dubio prosocietate. 2. Os fatos serão melhor elucidados no decorrer do desenvolvimento da ação penal, devendo o processo tramitar no Juízo Comum, por força do princípio in dubio pro societate que rege a fase do inquérito policial, em razão de que somente diante de prova inequívoca deve o réu ser subtraído de seu juiz natural. Se durante o inquérito policial, a prova quanto à falta doanimus necandi não é inconteste e tranqüila, não pode ser aceita nesta fase que favorece a sociedade, eis que não existem evidências inquestionáveis para ampará-la sem margem de dúvida. 3. O parágrafo único do art. $9^{\circ}$ do CPM, com as alterações introduzidas pela Lei $n^{0} 9.299 / 96$, excluiu do rol dos crimes militares os crimes dolosos contra a vida praticado por militar contra civil, competindo à Justiça Comum a competência para julgamento dos referidos delitos. 4. Conflito conhecido para declarar competente o Juízo de Direito da $1^{\mathrm{a}}$ Vara Criminal do Tribunal do Júri de Porto Alegre - RS. (STJ; CC 113.020; Proc. 2010/0111378-0; RS; Terceira Seção; Rel. Min. Og Fernandes; Julg. 23/03/2011; DJE 01/04/2011)

É o mesmo seguido pelo Tribunal Regional Federal que prega a necessidade de se provar a responsabilidade criminal ou não durante o Iter processual:

PENAL. PROCESSUAL PENAL. RECURSO EM SENTIDO ESTRITO. REJEIÇÃO DA DENÚNCIA. ART. 289, § 1º, DO CP. MOEDA FALSA. LAUDO PERICIAL. FALSIFICAÇÃO PASSÍVEL DE LUDIBRIAR O HOMO MEDIUS. COMPETÊNCIA DA JUSTIÇA FEDERAL INAPLICABILIDADE DA SÚMULA No 73 DO STJ. GUARDAR MOEDA FALSA. CONDUTA TÍPICA. INDÍCIOS SUFICIENTES DA AUTORIA E DA MATERIALIDADE DO DELITO. RECEBIMENTO DA PEÇA ACUSATÓRIA. RECURSO PROVIDO. I. A 
conclusão do laudo pericial no sentido de que as cédulas possuem qualidade suficiente para se passarem por autênticas, no meio circulante, iludindo o homo medius. Tal como efetivamente ocorreu, na espécie -, denota, em tese, a prática do delito de moeda falsa (art. 289, $\S 1^{\circ}$, do CP), a ser processado e julgado pela justiça federal, inaplicando-se, in casu, a Súmula $n^{\circ} 73$ do STJ. II. Apenas a utilização de papel moeda grosseiramente falsificado configura, em tese, o crime de estelionato, da competência da Justiça Estadual (Súmula $\mathrm{n}^{\circ}$ 73/STJ). III. Para que se caracterize o delito de moeda falsa, é imprescindível que o produto fabricado ou alterado guarde semelhança com o verdadeiro, capaz de se confundir com o autêntico, não o descaracterizando, contudo, o fato de a imperfeição ser percebida num exame atento, por pessoas que rotineiramente manuseiam valores. (acr 2003.38.00.056009-4/MG, Rel. Juiz federal convocado guilherme doehler, $3^{\mathrm{a}}$ turma do TRF/1 ${ }^{\mathrm{a}}$ região, unânime, DJU de 09/09/2005, p. 38). IV. (...) 1. Guardar moeda falsa, tendo plena consciência de sua falsidade, é suficiente para ensejar a condenação no crime previsto no art. 289, $\S 1^{\circ}$, do Código Penal brasileiro. (TRF/1 ${ }^{\mathrm{a}}$ região, acr 0000852-25.2007.4.01.4200/RR, $4^{\mathrm{a}}$ turma, Rel. Conv. Juiz federal marcus vinícius reis bastos, unânime, in e-djf1 de 25/10/2010) V. Demonstrados, na denúncia, suficientes indícios de autoria e a materialidade do delito, com preenchimento dos requisitos constantes do art. 41 do código de processo penal, impõe-se o seu recebimento, mormente em face da prevalência, nessa fase processual, do princípio in dubio pro societate. VI. Recurso provido. (TRF $1^{\mathrm{a}}$ R.; RSE 33267-68.2005.4.01.3800; MG; Terceira Turma; Rel. Juiz Fed. Conv. Klaus Kuschel; Julg. 07/06/2011; DJF1 15/07/2011; Pág. 25)

Outra linha jurisprudencial, capitenada pelo ex-desembargador do Tribunal de Justiça do Rio Grande do Sul, Aramis Nassif, prega que esta incidência do in dubio pro societate ocorre apenas no momento de se receber a denúncia, não afetando casos de júri, pois, após o oferecimento da peça acusatória "Nesta fase processual, para o recebimento da denúncia, vige o princípio do in dúbio pro societate, ou seja, havendo dúvida quanto a certeza da autoria deve ser recebida a denúncia ofertada, desde eu amparada em elementos indicativos da existência do fato e sua autoria"15.

A dúvida na acusação reflete-se em uma opção do julgador por credibilizar os entes estatais em detrimento do acusado.

\section{DA FALTA DE FUNDAMENTO LEGAL PARA O FAMIGERADO TERMO E DA SABOTAGEM CONSTITUCIONAL CAUSADA POR SEU USO}

Em qualquer dos dois momentos processuais em que é acionado o conveniente ditado popular, existe a crítica bastante vultosa por parte da doutrinada, todas, em regra, buscando suporte no válido e histórico princípio do in dúbio pro reo.

Consoante aplicação no procedimento especial do júri,Gustavo Henrique Righi Badaró, a exemplo, apresenta argumento exatamente na linha do in dúbio pro reo:

\footnotetext{
${ }^{15}$ Habeas Corpus No 70030357081, Quinta Câmara Criminal, Tribunal de Justiça do RS, Relator: Aramis Nassif, Julgado em 24/06/2009
} 
Discorda-se desse entendimento. Com relação à materialidade, o art. 413, caput, do CPP estabelce um critério de certeza: o juiz "se convencer" da existência do crime. Assim, se houver dúvida quanto a haver ou não prova da existência do crime, o acusado deve ser impronunciado. Já com realção à autoria, o requisito legal não exige certeza, mas sim a probabilidade da autoridade delitiva: deve haver "indicios suficientes" da autoria. É claro que o juiz não precisa ter certeza ou "se convencer" da autoria. Mas se estiver na dúvida se estão ou não presentes os "indícios suficientes de autoria", deverá impronunciar o acusado, por não ter sido atendido o requisito legal. Aplica-se, pois, na pronúncia, o in dubio pro reo. ${ }^{16}$

Fernando da Costa Tourinho Filho altera o foco crítico e aborda o fato de que os jurados, juízes de fato sem dever de fundamentar o que decidem, podem julgar por qualquer íntima razão que lhes pareça adequada. Portanto, como a retórica pode exercer papel decisivo em um julgamento pelo tribunal do júri, o sujeito submetido ao tribunal sem provas, que pode presumidamente inocente, pode, por capricho, ser condenado:

De outra banda, quando da pronúncia, se o Juiz não estiver seguro de que a condenação é de rigor, cumpre-lhe impronunciar ou absolver o réu, conforme o caso, mesmo porque não se concebe, em face da gravidade da pena, possa o Magistrado permitir que o réu seja submetido a um julgamento soberano, em que muitas vezes a eloqüência do Acusador exerce certo fascínio, levando o Conselhor de Sentença a proferir decisão condenatória. ${ }^{17}$

Aramis Nassif e André Keppler Fraga apresentam convincente explicação da importância e da responsabilidade da pronúncia para, exatamente, evitar o risco apresentado por Tourinho Filho de uma condenação de inocente, visto que "A pronúncia, portanto, funciona como uma garantia ao réu, de modo a impedir que alguém seja condenado sem que haja elementos probatórios válidos a ampará-la". ${ }^{18}$

Como já visto, segundo o senso comum, a dúvida sobre a autoria deveria fazer o magistrado, ao decidir, encaminhar o acusado para ser julgador pelos jurados. Ora, como pode uma garantia do acusado servir contra ele próprio?

A resposta a essa pergunta vem com o uso instrumental de um princípio, que é a soberania dos veredictos que seria responsável por dar um ar constitucional ao in dubio pro societate. No entanto, esse entendimento é uma extensão indevida e uma extração de sentido inexistente de um preceito que visa assegurar que, quando houver julgamento, os jurados são os juízes do fato e que nem mesmo em sede recursal suas decisões poderão ser alteradas.

Tanto é que os recursos em casos de julgamento pelo tribunal do júri são de fundamentação vinculada e submetidos as súmulas 160 e 713 do Supremo Tribunal Federal.

\footnotetext{
${ }^{16}$ BADARÓ, Gustavo Henrique Righi Ivahy. Direito Processual Penal. Tomo II. $2^{\mathrm{a}}$ ed. Rio de Janeiro: Elsevier, 2009, p. 79.

${ }^{17}$ TOURINHO FILHO, Fernando da Costa. Processo penal. vol. IV. $32^{\mathrm{a}}$ ed. São Paulo: Saraiva, 2010, p. 157.

${ }^{18}$ BOSCHI, Marcus Vinicius. Código de Processo Penal Comentado. Porto Alegre: Livraria do advogado, 2008, p. 342.
} 
A soberania dos veredictos não significa que na dúvida o conselho de sentença decide e sim que as decisões desse conselho são soberanas, mas, como em qualquer processo, devem ser pautadas por elementos probatórios idôneos e, acima disso, devem ser elaboradas sob a luz de um processo devido que é aquele que respeita os densificadores constitucionais processuais penais garantistas.

Então, "O chamado princípio do in dubio pro societate não é compatível com o Estado Democrático de Direito, onde a dúvida não pode autorizar uma acusação, colocando uma pessoa no banco dos réus [...]". ${ }^{19}$

Aury Lopes Jr., expõe com acerto os contornos da soberania dos veredictos alegando que "A soberania diz respeito a competência e limites ao poder de revisar as decisões do júri. Nada tem a ver com carga probatória". ${ }^{20}$

Paulo Rangel faz uma referência bastante forte e se alinha ao que prega Aury Lopes Jr., quanto ao fato de que o in dubio contra reo é um conveniência processual infundada:

Não há nenhum dispositivo legal que autorize esse chamado princípio do in dubio pro societate. O ônus da prova [...] é do Estado e não do investigado. Jogá-lo no banco dos réus com a alegação de que na instrução o MP provará os fatos que alegou é achincalhar com os direitos e garantias individuais, desestabilizando a ordem jurídica com sérios comprometimentos ao Estado Democrático de Direito. ${ }^{21}$

A decisão de pronúncia não pode, ao mesmo tempo, violar direitos do acusado, criar presunção de prova e uma confiabilidade na acusação tão firme a ponto de alterar a sua função, que, aliás, é a de submeter o acusado a júri quando existirem "fortes elementos probatórios de autoria e materialidade". ${ }^{22}$

Com acerto, Vicente Greco Filho fala da função da pronúncia e aponta o erro comum que é repetido por operadores do direito:

É comum dizer-se que a função da pronúncia é a de remeter o réu a Júri. Mas rejeitamos, terminantemente, essa impostação. A função da fase de pronúncia é, exatamente, a contrária. Em outras palavras, a funçãó do juiz toga do, na fase de pronúncia, é a de evitar que alguém que não mereça ser condenado possa sê-lo em virtude do julgamento soberano, em decisão, quiçá, de vingança pessoal ou social. Ou seja, cabe ao juiz na fase de pronúncia excluir do julgamento popular aquele que não deva sofrer a repressão penal. Usando expressões populares, pode-se dizer que compete ao juiz evitar que um inocente seja jogado 'às feras', correndo o risco de ser condenado, ou que o Júri pode fazer uma injustiça absolvendo, não podendo fazer uma injustiça ao condenar. A pronúncia, portanto, atua como uma garantia da liberdade, evitan-

\footnotetext{
${ }^{19}$ RANGEL, Paulo. Direito Processual Penal. $13^{\mathrm{a}}$ ed. Rio de Janeiro: Lumen Juris, 2007, p. 79.

${ }^{20}$ LOPES JR., Aury. Direito processual penal e sua conformidade constitucional. Vol. II. Rio de Janeiro: 2009, p. 261.

${ }^{21}$ RANGEL, Paulo. Direito Processual Penal. $13^{\mathrm{a}}$ ed. Rio de Janeiro: Lumen Juris, 2007, p. 593.

${ }^{22}$ LOPES JR., Aury. Direito processual penal e sua conformidade constitucional. Vol. II. Rio de Janeiro: 2009, p. 262.
} 
do que alguém seja condenado e não o mereça. ${ }^{23}$

A doutrina constróe, a cada dia, uma nova linha de defesa contra este brocardo, até mesmo porque sua origem decorre de uma omissão que descamba ao ataque constitucional.

Esta verdadeira sabotagem à constituição, galgada pela pertinência e pelo comodismo de não se produzir prova e contar com o resultado futuro, é, segundo a promotora Ana Claudia Bastos de Pinho uma mostra de um empoeirado entendimento do que é processo e do que se deve(ria) garantir ao acusado:

As alterações pontuais são imprescindíveis e urgentes, é bom que se repita. Porém, além disso, necessária se faz uma verdadeira mudança de mentalidade por parte dos operadores jurídicos, no sentido de pensar o processo penal, não mais como uma obrigatória necessidade de implementar a "luta contra o crime" para assegurar a "ordem social", mas como um legítimo instrumento a serviço de um Direito Penal democrático e, acima de tudo, a serviço dos direitos fundamentais do cidadão.

A relação entre processo e Estado é inconteste, já que o processo é uma manifestação do Direito positivo e este, por óbvio, influenciado por razões de ordem política, sociológica, cultural que inspiram o exercício do poder estatal. [...] Pois bem, o que temos, hoje, no Brasil? Um sistema processual penal codificado às luzes fascistas da Era Vargas em confronto com uma Constituição Federal garantista, que consagrou, como fundamento do Estado Democrático de Direito, a dignidade da pessoa humana e elevou a dogma de princípio maior, dentre outros, a presunção do estado de inocência. ${ }^{24}$

A reação, como visto, precisa se iniciar com a observação da nova dinâmica e lógica processual que não pode submeter o sujeito de direitos ao julgamento em um sistema de roleta russa.

De mais a mais, importante lembrar que: "a visão que se combate é ultrapassada; não tem recepção constitucional: o Júri é uma garantia do cidadão, não da sociedade!". ${ }^{25}$

E quanto ao uso do in dubio pro societate no recebimento da denúncia?

Levar um sujeito a responder ao processo sem um substrato probatorio sólido é, no mais das vezes, deixar transparente uma confiança maior do que o possível em uma parte processual.

Mais que isso, em uma situação de falta de provas na denúncia, não se pode confiar em uma parte e desconfiar da outra, não se pode violar assim tão ferozmente a Paridade de Armas em sentido material a ponto de se criar um processo que viole preceitos diversos apenas em razão da confiança

${ }^{23}$ FILHO, Vicente Greco. Questões Polêmicas Sobre a Pronúncia", em "Tribunal do Júri: estudo sobre a mais democrática instituição jurídica brasileira"/ coordenação Rogério Lauria Tucci. São Paulo: Ed. Rev. dos Tribs., 1999, p. 118-9

${ }_{24}$ PINHO, Ana Cláudia Bastos de. In dubio pro societate $\mathrm{x}$ processo penal garantista. Disponível em http://alexandremoraisdarosa.blogspot.com/2009/06/puxada-de-orelhamerecida.html. Acesso em 15/07/2011.

${ }^{25}$ PERES, César. Sentença de pronúncia: "in dubio pro societate"?. In: Âmbito Jurídico, Rio Grande, 22, 31/08/2005 [Internet]. Disponível em http://www.ambitojuridico.com.br/site/index.php?n_link=revista_artigos_leitura\&artigo_id 
acusatória, tanto é que a doutrina se posiciona no sentido de não se receber a denúncia sem lastro:

Não há que se falar em 'in dubio pro societate' no momento do recebimento da denúncia. Há duas dúvidas nesse instante decisório: uma aceitável e que não deve ser

resolvida; outra impeditiva da continuidade da perseguição. A dúvida aceitável é aquela quanto ao mérito da causa, ou seja, a que versa sobre a culpa pelo crime. Não é esta que o juiz deverá enfrentar ou resolver no instante do recebimento da denúncia. Deverá decidir, segundo a imposição constitucional do 'in dubio pro reo', uma outra dúvida, a referente à legitimidade para a continuidade da persecução. ${ }^{26}$

Não se pode também olvidar que o próprio Código de Processo Penal nos incisos do art. 395 faz referência expressa à rejeição quando a denúncia for carente.

\section{DA REAÇÃO DOS TRIBUNAIS EM BUSCA DE ADEQUAÇÃO DO PROCESSO COM A DIGNIDADE}

Os Tribunais, compreendendo a multiplicidade de ataques técnicos ao uso do in dubio pro societate e a própria natureza desse brocardo, proferiram diveros julgados retirando do pedestal da unanimidade o suposto preceito.

Evandro Lins e Silva ensina a muito e faz uma interessante comparação:

O juiz lava a mão como Pilatos e entrega o acusado (que ele não condenaria) aos azares de um julgamento no Júri, que não deveria ocorrer, pela razão muito simples de que o Tribunal de Jurados só tem competência para julgar os crimes contra a vida quando este existe, há prova de autoria ou participação do réu e não está demonstrada nenhuma excludente ou justificativa. ${ }^{27}$

Dentro de tal quadro reativo, o mais forte ataque ao brocardo é relatado pelo Desembargador José Mauricio Pinto de Almeida do Tribunal de Justiça do Paraná:

EMBARGOS INFRINGENTES. PRONÚNCIA. RECURSO EM SENTIDO

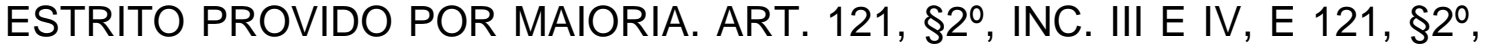
INC. III E IV, CC ART. 14, INC. II, POR 15 VEZES, TODOS CC ART. 69 DO CP. DECISÃO DE PRONÚNCIA COM BASE EM INDÍCIOS QUE NÃO ENSEJAM CONCLUSÃO DE TER A RÉ AGIDO COM DOLO. FATOS QUE NÃO EVIDENCIAM A VONTADE LIVRE E CONSCIENTE DE MATAR. EXAME QUE NÃO PODE MANTER-SE NO CAMPO DA SUBJETIVIDADE DO JULGADOR. DESCLASSIFICAÇÃO QUE MERECE SER OPERADA. IN DUBIO PRO SOCIETATE. PRINCÍPIO A SER APLICADO COM PARCIMÔNIA. TRIBUNAL DO JÚRI: GARANTIA CONSTITUCIONAL, E NÃO

${ }^{26}$ MORAES, Maurício Zanoide de. Presunção de Inocência no Processo Penal Brasileiro: análise de sua estrutura normativa para a elaboração legislativa e para a decisão judicial. Rio de Janeiro: Lumen Juris, 2010, p. 418.

${ }^{27}$ LINS E SILVA, Evando. Artigo do Boletim IBCCRIM no 100 Março/2001 
INSTITUIÇÃO A JULGAR CASO EM QUE NÃO RESTOU EVIDENCIADA A CONDUTA DOLOSA. DESPRONÚNCIA DE TENTATIVAS DE HOMICÍDIO CULPOSO (SEM LESÕES) POR AUSÊNCIA DE TIPIFICAÇÃO. RECURSO PROVIDO. 1.Para que o feito seja encaminhado a julgamento pelo Tribunal do Júri, necessário que se tenha evidenciado tratar-se de crime doloso contra a vida; não encontrando tal respaldo nos autos, deve o julgador operar a desclassificação, encaminhando para julgamento pelo juízo competente. 2.Não se pode admitir a pronúncia com base em fatos exteriores que poderiam supor ter o agente atuado com dolo, assim como não é viável aceitarem-se indícios que permanecem no campo da subjetividade, os quais dependem da maneira de interpretarem-se os fatos ocorridos. 3."(...) o 'in dubio pro reo' conecta-se umbilicalmente à estirpe de dogma constitucional instransponível: 0 art. $5^{\circ}$, LVII, da Constituição da República reforça o princípio 'in dubio pro reo'. Embora não exista dispositivo aparente que mencione, textualmente, a expressão 'in dubio pro reo', é inegável seu laço de consanguinidade com a Lei Maior, o que não acontece com o 'in dubio pro societate' - este sim, sem pai nem mãe, filho de tubo de ensaio, filhote do laboratório pretoriano, monstrengo bizarro e esquizóide de uma criação artificial, uma espécie de Frankstein jurídico, que deve ser expurgado da jurisprudência. Aliás, essa execrável dicotomia entre 'indubio pro reo' e 'in dubio pro societate' sugere que os interesses do acusado são contrapostos aos da sociedade, o que é insustentável, ao menos, num sistema de base garantista. Com efeito, o princípio 'indubio pro reo' é um princípio 'pro societate', porque é um princípio pro garantia undividual, proConstituição, pro Estado Democrático de Direito. Aquilo que se tem como 'princípio in dúbio prosocietate', em verdade, não tem nada de pro sociedade. Ao contrário, é contra a democracia, contra as liberdades individuais, contra, portanto, a própria sociedade.(...) Não se pode concordar plenamente com a ideia, porque a dúvida - seja sobre questões de direito, seja sobre questões de fato - é sempre dúvida, e, portanto, como tal, como dúvida que é, deve ser revertida, sempre e sempre, em favor do acusado" - (ADRIANO SÉRGIO NUNES BRETAS. "O ESTIGMA DE "PILATOS - DESCONSTRUINDO O MITO 'INDUBIO PRO SOCIETATE' DA PRONÚNCIA NO RITO JÚRI". Curitiba: Bretas Advocacia, 2008, p. 21-23). 4."Submeter alguém presumivelmente inocente sob o argumento de que há indícios de autoria, ainda que não vagos, e de que existe a prova de materialidade, ao Tribunal do Júri, deixando para que o santo do dia faça o milagre, é desconsiderar a Constituição Federal" (Desembargador Mário Helton Jorge, voto vencido, fl. 1.218). (TJPR - 2a C.Criminal em Com. Int. - EIC 0445954-3/01 - Cascavel Rel.: Des. José Mauricio Pinto de Almeida - Unânime - J. 19.02.2009)

Remete o relator a obra de Adriano Sergio Nunes Bretas que faz uma necropsia do brocardo que tem lição que não difere da analise feita por Fauzi Hassan Choukr, “Tal 'princípio' não existe fora do seu mero emprego retórico (e este emprego existe à saciedade) e ele nada mais é que fruto direto das manipulações discursivas ideológicas que alteraram as estrutura dos Tribunal do Júri". ${ }^{28}$

O primeiro aponta, em suas conclusões, que:

${ }^{28}$ CHOUKR, Fauzi Hassan. Còdigo de Processo Penal. Comentários consolidados e crítica jurisprudencial. $4^{\mathrm{a}}$ ed. Rio de Janeiro: Lumen Juris, 2010, p. 664. 
[...] como existe efeitos nocivos decorrentes da pronúncia, vigora na fase da pronúncia o princípio in dubio pro reo, por variegadas razões: seja, porque não há suporte legal no ordenamento para acomodar o in dubio pro societate; seja, porque o legislador previu a chance do acusado ser absolvido sumariamente; seja, por que o júri não precisa fundamentar suas decisões; seja, enfim, porque a Constituição da República assim o estabeleceu. ${ }^{29}$

Eis alguns julgados que afastaram o brocador do momento da apreciação da pronúncia:

RECURSO EM SENTIDO ESTRITO 2009.051.00265 RECORRENTE: MARCELO FLORÊNCIO NOGUEIRA RECORRIDO: MINISTÉRIO PÚBLICO JUÍZO: 2. ${ }^{a}$ VARA DA COMARCA DE SÃO JOÃO DA BARRA RELATOR: DESEMBARGADOR GERALDO PRADO Artigo 121, § 2. ${ }^{\circ}$, inciso II, do Código Penal. EMENTA: PROCESSO PENAL. RECURSO EM SENTIDO ESTRITO. HOMICÍDIO QUALIFICADO POR MOTIVO FÚTIL. PRONÚNCIA. IMPOSSIBILIDADE DE CONSIDERAÇÃO DOS ELEMENTOS COLHIDOS NA FASE INVESTIGATIVA, SOB PENA DE VIOLAÇÃO AO CONTRADITÓRIO, À PRESUNÇÃO DE INOCÊNCIA E AO DEVIDO PROCESSO LEGAL. ESPECULAÇÕES DE TESTEMUNHAS QUE, POR SEREM INSUSCETÍVEIS DO CONTROLE PELO CONTRADITÓRIO, NÃO CONFIGURAM OS INDÍCIOS EXIGIDOS PARA A DECISÃO DE PRONÚNCIA. QUADRO DE PROBABILIDADE DA AUTORIA, EXIGIDO PARA A REMESSA DA CAUSA À APRECIAÇÃO DO CONSELHO DE SENTENÇA, QUE NÃO SE VERIFICA. Recorrente denunciado e pronunciado para responder, perante o Tribunal do Júri, pela prática do crime definido no artigo $121, \S 2 .^{\circ}$, inciso II, do Código Penal. Vedação à consideração de elementos colhidos na fase investigativa para a condenação, especialmente com o advento da Lei 11.690/08, que modificou a redação do artigo 155 do Código de Processo Penal para definir a prova como aquela produzida em "contraditório judicial", tornando taxativas as exceções legais a essa proibição. Especulações de testemunhas a respeito da autoria que, além de insuscetíveis de controle pelo contraditório, estão timidamente corroboradas pelo fato de o acusado ter visitado a vítima dias antes do crime e perguntado quando ela ficaria sozinha. Ausência de relação de causalidade entre esse fato e a morte da vítima. Inexistência de pluralidade de provas circunstanciais. Cenário de autoria construído sob o mero juízo de possibilidade, insuficiente à remessa da causa à apreciação do Tribunal do Júri, que implica a assunção do risco de, sob a égide do princípio da íntima convicção, condenar-se um provável inocente. Inaplicabilidade do princípio in dubio pro societate.

RECURSO EM SENTIDO ESTRITO MINISTERIAL. SENTENÇA DE PRONÚNCIA QUE AFASTOU O MOTIVO TORPE. QUALIFICADORA

${ }^{29}$ BRETAS, Adriano Sérgio Nunes. Estigma de pilatos: A desconstrução do mito do In dubio pro societate na pronúncia no rito do júri e a sua repercussão jurisprudencial. Curitiba: Juruá, 2010, p. 42. 
MANIFESTAMENTE

IMPROCEDENTE.

INAPLICÁVEL

$\mathrm{O}$

PRINCÍPIO IN DUBIO PROSOCIETATE. NÃO PROVIDO. A qualificadora do motivo torpe é narrada na denúncia consubstanciada no desejo de eliminar a vida de terceira pessoa em razão de desavenças anteriores por brigas de gangues, e, por erro de execução, a vítima foi atingida. Referida argumentação mostra-se nos autos manifestamente improcedente, isto é, completamente destituída de amparo nos elementos cognitivos do processo. Das provas produzidas, conclui-se que a qualificadora narrada na denúncia não condiz com o verdadeiro móvel do delito, que, em tese, seria o fato de o réu ter ficado com raiva em razão de ter levado um tapa no rosto de um terceiro (denominado na denúncia vítima virtual) que estava em companhia da vítima (chamado na peça acusatória vítima real). (TJMS; RSE 2011.015061-5/0000-00; Campo Grande; Primeira Turma Criminal; Rel. Des. Dorival Moreira dos Santos; DJEMS 15/07/2011; Pág. 29)

RECURSO CRIMINAL. HOMICÍDIO SIMPLES DECORRENTE DE ATROPELAMENTO. DECISÃO QUE RECONHECE O DOLO EVENTUAL. PUGNADA ABSOLVIÇÃO SUMÁRIA. PROVIDÊNCIA QUE SOMENTE SERIA POSSÍVEL, NESTA FASE, SE DA PROVA COLETADA SE PUDESSE ATRIBUIR A PRÁTICA DO DELITO A OUTRA PESSOA. CIRCUNSTÂNCIA NÃO EVIDENCIADA. MATERIALIDADE COMPROVADA E INDÍCIOS SUFICIENTES DA AUTORIA. DESCLASSIFICAÇÃO PARA CRIME DE TRÂNSITO. INEXISTÊNCIA DE ELEMENTO CONCRETO QUE DEMONSTRE TER O RÉU ANUÍDO AO RESULTADO MORTE. CARACTERIZAÇÃO DE CULPA. RECURSO PARCIALMENTE PROVIDO. 1 No momento do judicium acussationis é necessária a análise do elemento subjetivo do tipo, para pronunciar, tão-somente, os crimes contra a vida cometidos com dolo (direto ou eventual); evitando, pois, lançar à sorte, em nome do princípio do in dubio pro societate, os crimes cometidos a título de culpa (consciente ou inconsciente). Caso contrário, seriam totalmente infundadas as hipóteses de desclassificação, impronúncia ou absolvição sumária. 2 "a atitude ética da indiferença é o elemento nuclear ou, pelo menos, o ponto de passagem obrigatório para a global compreensão do dolo eventual" (josé de faria costa). 3 "não se pode partir do princípio de que todos aqueles que dirigem embriagados e com velocidade excessiva não se importem em causar a morte ou mesmo lesões em outras pessoas, [... ] o clamor social no sentido de que os motoristas que dirigem embriagados e/ou em velocidade excessiva devem ser punidos severamente, quando tiram a vida ou causem lesões irreparáveis em pessoas inocentes, não pode ter o condão de modificar toda a nossa estrutura jurídicopenal" (min. Paulo medina). (TJSC; RCR 2011.006130-1; Xanxerê; Terceira Câmara Criminal; Rel. Des. Moacyr de Moraes Lima Filho; Julg. 21/06/2011; DJSC 13/07/2011; Pág. 394)

APELAÇÃO CRIMINAL. TENTATIVA DE HOMICÍDIO EM CONCURSO FORMAL IMPRÓPRIO CP, ART. 121, CAPUT, C/C ART. 14, II, NA FORMA DO ART. 70, IN FINE, TODOS DO CP). IMPRONÚNCIA (CPP, ART. 414). INCONFORMISMO MINISTERIAL. PRETENSA PRONÚNCIA. IMPOSSIBILIDADE. AUSÊNCIA DE PROVAS JUDICIALIZADAS (CPP, ART. 
155, CAPUT). CONJUNTO PROBATÓRIO ANÊMICO. SENTENÇA MANTIDA. RECURSO DESPROVIDO. I. De acordo com o disposto no art. 414, do cpp, "não se convencendo da materialidade do fato ou da existência de indícios suficientes de autoria ou de participação, o juiz, fundamentadamente, impronunciará o acusado. " outrossim, é cediço que "o juiz formará sua convicção pela livre apreciação da prova produzida em contraditório judicial, não podendo fundamentar sua decisão exclusivamente nos elementos informativos colhidos na investigação, ressalvadas as provas cautelares, não repetíveis e antecipadas" (cpp, art. 155, caput). dessa forma, apesar de a sentença de pronúncia ser de índole precária e provisória, esta deve possuir condições probatórias mínimas para submeter o cidadão ao processo criminal perante o tribunal do júri, em face das garantias constitucionais da ampla defesa e do contraditório ( $\mathrm{CF} / 88$, art. $5^{\circ}$, IV). a propósito, o disposto no art. 155 , caput, do cpp, é plenamente aplicável à fase da pronúncia, não sendo possível, portanto, a admissibilidade de sentença positiva de pronúncia, somente com base em indícios apurados no inquérito, ainda que nesta fase vigore o princípio do in dubio pro societate. assim sendo, o fato de os jurados decidirem por íntima convicção, ou seja, sem fundamentar suas decisões, revela a razão para que a apreciação do feito não seja submetida ao conselho de sentença com prova exclusivamente inquisitorial, notadamente em face do raciocínio segundo o qual, se o réu, uma vez julgado por um juiz togado, não pode ser condenado exclusivamente por elementos constantes do inquérito policial, seria por demais desarrazoado que tal fosse permitido com relação aos que são julgados pelos juízes leigos. destarte, a prova produzida na fase policial somente poderá ser utilizada para justificar a pronúncia quando aliada a algum outro elemento produzido judicialmente, sob o crivo do contraditório. ii. Em não se vislumbrando nos autos nenhuma prova judicial para viabilizar um juízo de admissibilidade da acusação, a impronúncia é medida que se impõe, nos termos do art. 414 do cpp, sem prejuízo de renovação da denúncia, caso futuramente sobrevenham novas provas, conforme dispõe o parágrafo único do aludido dispositivo. (TJSC; ACr 2010.043233-2; São Francisco do Sul; Segunda Câmara Criminal; Rela Des ${ }^{a}$ Salete Silva Sommariva; Julg. 14/06/2011; DJSC 05/07/2011; Pág. 594)

O Supremo Tribunal Federal também já decidiu por não existir uma ditadura de tal preceito:

PROCESSO PENAL. CRIME DOLOSO CONTRA A VIDA. COMPETÊNCIA DE ASSENTO CONSTITUCIONAL. TRIBUNAL DO JÚRI. ABORTO SEM O CONSENTIMENTO DA GESTANTE. ALEGADA DEMORA NA REALIZAÇÃO DO PARTO PELO MÉDICO. QUADRO EMPÍRICO REVELADOR DA AUSÊNCIA DE AÇÃO DOLOSA E DE OMISSÃO IGUALMENTE INTENCIONAL. CAPITULAÇÃO JURÍDICA DA CONDUTA. ORDEM PARCIALMENTE CONCEDIDA. 1. O Supremo Tribunal Federal distingue entre a capitulação jurídica dos fatos (ou seja, o enquadramento típico da conduta) e o revolvimento de matéria fático-probatória. Motivo pelo qual, fixado o quadro empírico pelas instâncias competentes, pronunciamento desta colenda corte sobre o enquadramento jurídico da conduta não extrapola os limites da via processualmente contida do habeas corpus. 2. Na concreta situação dos autos, enquanto o juízo da vara do júri de sobral/CE rechaçou a tese da materialidade 
delitiva, embasado no mais detido exame das circunstâncias do caso, o voto condutor do acórdão do tribunal de justiça do Estado do Ceará (acórdão que pronunciou o paciente contra até mesmo a manifestação do ministério público estadual) limitou-se a reproduzir, ipsis literis, os termos da denúncia. Reprodução, essa, que assentou, de modo totalmente alheio às contingências fáticas dos autos, a prevalência absoluta da máxima in dubio prosocietate. Desconsiderando, com isso, as premissas que justificam a incidência da excepcional regra do $\S 2^{\circ}$ do art. 13 do Código Penal. 3. Premissas que não se fazem presentes no caso para assentar a responsabilização do paciente por crime doloso, pois: A) o paciente não se omitiu; ao contrário, atendeu a gestante nas oportunidades em que ela esteve na casa de saúde; b) o paciente não esteve indiferente ao resultado lesivo da falta de pronto atendimento à gestante; c) o paciente agiu, dentro do possível, para minimizar os riscos que envolvem situações como a retratada no caso. 4. Ordem parcialmente concedida. (STF; HC 95.068-0; CE; Primeira Turma; Rel. Min. Carlos Britto; Julg. 17/03/2009; DJE 15/05/2009; Pág. 127

O Superior Tribunal de Justiça, em diversos acórdãos relatados pela Ministra Maria Thereza de Assis Moura, afastou o in dubio pro societate do momento de apreciar a denúncia e verificar de sua possibilidade de ser recebida.

Paradigmático é o acórdão do HC 84.579 PI julgado pela Sexta Turma:

PROCESSO PENAL. HABEAS CORPUS. ART. 89, PAR. ÚNICO DA LEI DE LICITAÇÕES. ESTELIONATO CIRCUNSTANCIADO. DENÚNCIA. FALTA DE JUSTA CAUSA. ATIPICIDADE. RECONHECIMENTO. 1. A acusação, no seio do Estado Democrático de Direito, deve ser edificada em base sólidas, corporificando a justa causa, sendo abominável a concepção de um chamado princípio in dubio pro societate. In casu, a indicação do próprio domicílio como sede de pessoa jurídica, de que se é despachante, indicando que seria o imputado próximo da empresa beneficiada pela licitação inidônea e pelas fraudes perpetradas, per se, não implica correspondência com os modelos incriminadores dos crimes do parágrafo único do art. 89 da Lei de Licitações e de estelionato circunstanciado. 2. Ordem concedida para trancar, apenas em relação ao paciente, a Ação Penal n. ${ }^{\circ}$ 2007.8300081-0, em curso na 13 Vara Seção Judiciária de Recife/PE. (HC 84.579/PI, Rel. Ministra MARIA THEREZA DE ASSIS MOURA, SEXTA TURMA, julgado em 11/05/2010, DJe 31/05/2010)

No voto da relatora, acompanhado pelos demais componentes da Sexta Turma,

É importante destacar: a acusação, no seio do Estado Democrático de Direito, deve ser edificada sobre bases sólidas, as quais dão vida ao conceito de justa causa. Assim, é abominável a concepção de um chamado princípio in dubio pro societate. [...] Como salientava Carnelutti, em as Misérias do Processo Penal, a tão só existência da persecutio já configura, em si mesma, uma pena para o réu. Os dissabores da pesada intervenção estatal são deveras estigmatizantes, daí a necessidade de cuidado no seu trato. Desde que se optou por um modelo de Estado de cariz democrático, em que se assinala a dignidade da pessoa humana como seu fundamento, a atuação repressiva deve ser excepcional, somente justificada com 0 atendimento dos requisitos legais, faticamente demonstrados. Ao que me é 
dado apreciar, na estreita via do writ, acredito que o Estado precipitou-se, devendo a ação penal ser trancada, apenas em relação ao paciente, diante da inépcia material da denúncia. Percebo clara tentativa de se irrogar responsabilidade penal objetiva.

Não é isolada a decisão acima, tanto que a Sexta Turma do STJ já repetiu a decisão várias vezes:

PROCESSO PENAL. HABEAS CORPUS. HOMICÍDIO DUPLAMENTE QUALIFICADO. IMPRONÚNCIA: PROVAS INSUFICIENTES DE AUTORIA. RECURSO MINISTERIAL. ACÓRDÃO QUE MANDA O PACIENTE A JÚRI. INDÍCIOS DE AUTORIA. ELEMENTOS COLHIDOS NA FASE POLICIAL: DEPOIMENTO DE TESTEMUNHA PROTEGIDA E CONFISSÃO. NÃO REPETIÇÃO EM JUÍZO. VALORAÇÃO DA PROVA. IMPOSSIBILIDADE. 1. Por mais que não se acolha o princípio in dubio pro societate, para o juízo de pronúncia bastam indícios de autoria. In casu, o juiz de primeiro grau, ao impronunciar o paciente, destacara a insuficiência de provas. Já o Sodalício local sublinhou que a confissão e o depoimento de testemunha protegida, ambos colhidos na fase policial e não repetidos em juízo, representam, em sintonia com as demais provas amealhadas, corpo instrutório seguro o bastante para sujeitar o paciente ao julgamento pelo tribunal leigo. Neste contexto, é inviável a esta Corte revolver toda a prova para aferir o acerto da pronúncia. 2. Ordem não conhecida. (HC 171.612/SP, Rel. Ministra MARIA THEREZA DE ASSIS MOURA, SEXTA TURMA, julgado em 03/02/2011, DJe 28/02/2011)

RECURSO ESPECIAL. DESPRONÚNCIA. AUSÊNCIA DE ELEMENTOS INDICIÁRIOS DA AUTORIA. MATÉRIA PROBATÓRIA. SÚMULA 7. A Corte de origem, ao desvendar a inexistência de indícios mínimos de autoria, tornou a controvérsia somente apurável em nível de cotejo probatório, o que recomenda a aplicação da Súmula 7 desta Corte. Não se é de verificar a prevalência do princípio do in dubio pro societate, no juízo de pronúncia, se nem ao menos restaram comprovados indícios suficientes de autoria, circunstância a ser considerada para permitir a despronúncia. Recurso não conhecido. (REsp 1010570/DF, Rel. Ministra MARIA THEREZA DE ASSIS MOURA, SEXTA TURMA, julgado em 16/11/2010, DJe 29/11/2010)

PROCESSO PENAL. HABEAS CORPUS. EXTORSÃO E CÁRCERE PRIVADO. INQUÉRITO POLICIAL. ELEMENTOS INFORMATIVOS CONTRADITÓRIOS. EMBASAMENTO FÁTICO PARA A AÇÃO PENAL. AUSÊNCIA. 1. A princípio, o inquérito policial apenas fornece elementos informativos, que se prestam para a formação da opinio delicti do órgão acusador. Em um Estado de Direito que se pretende Democrático não há espaço para a máxima in dubio pro societate. Pelo contrário, para a sujeição do indivíduo aos rigores do processo penal é indispensável que a Polícia amealhe elementos informativos suficientes e iluminados pela coerência - sob pena de se iniciar uma ação penal iníqua e inócua, carente, pois, de justa causa. 2. In casu, foi oferecida denúncia contra o paciente, calcando-se em inquérito 
policial que, tendo tramitado por sete anos, não logrou estabelecer o, minimamente seguro, liame entre o comportamento do paciente $e$ as imputações. 3. Ordem concedida para determinar o trancamento da ação penal apenas em relação apenas ao paciente (processo controle n. ${ }^{\circ} 297 / 2001$, da $1 .^{a}$ Vara do Foro Distrital de Paulínia, da Comarca de Campinas/SP), sem prejuízo de oferecimento de nova denúncia, caso surjam novos e robustos elementos para tanto. (HC 147.105/SP, Rel. Ministra MARIA THEREZA DE ASSIS MOURA, SEXTA TURMA, julgado em 23/02/2010, DJe 15/03/2010)

A despeito do que foi ventilado acima, com farta e precisa jurisprudência, especialmente da Sexta Turma do Superior Tribunal de Justiça, em julgamentos relatados pela Ministra Maria Thereza de Assis Moura, ainda há, na Turma, divergência, como se percebe no HC 145.399 MG, relatado pelo desembargador Haraldo Rodrigues em 25 de outubro de 2010, posto que voltou a levar o réu a júri quando pairavam dúvidas no caso.

\section{CONCLUSÕES}

Pode-se perceber que existe uma tendência doutrinária de afastamento do in dubio contra reo ou pro societate na jurisprudência, o que acompanha as lições doutrinárias de maior envergadura e que, de fato, analisam a estrutura e a aplicação do brocador.

No primeiro capítulo, foi feita exposição do que a doutrina concebe como origem do princípio, captando a pesquisa a primeira raiz identificada como a do in dubio pro societate e se verificou a falta de berço do brocardo in dubio pro societate.

Já nos tópicos seguintes foi feita análisa da extensão deste quase preceito na jurisprudência dos tribunais superiores, o que demonstrou um discurso de repetição na situação da decisão da pronúncia e do recebimento da denúncia.

Demonstrou-se que a jurisprudência concebe a dúvida, nestes momentos, como defavorável ao acusado.

Em item a frente, demonstrou a concepção doutrinária sobre o in dubio pro societate e as críticas exaradas por doutrinadores que realizem análise mais detida das circunstâncias que orbitam sobre tal brocardo.

Isso demonstrou uma onda de reforma quanto ao uso deste semi-princípio especialmente nos casos de júri.

Após a análise doutrinária, passou-se a verificar na jurisprudência inumeros julgados de tribunais estaduais e superiores.

Concluí-se, por fim, que há fortes manifestações críticas com o uso indiscriminado do brocador, objeto deste estudo, sendo a tendência reformadora expandida verticalmente.

Encontram-se decisões dos tribunais estaduais afastando do procedimento especial do júri o brocador infame, o que evidencia uma maior preocupação com a técnica processual vinculada, como deve ser, aos preceitos constitucionais. 
No Superior Tribunal de Justiça a insurgência é quanto a aplicação do ditado quando do recebimento da denúncia, sendo que a aplicação de tal entendimento restringe-se à Sexta Turma do STJ, não encontrando ainda unanimidade.

Embora com divergências, há claras amostras de aproximação da técnica com os ditames constitucionais do processo os quais convergem, claro, para um processo que não faça ferimentos indevidos à Dignidade.

\section{BIBLIOGRAFIA}

BADARÓ, Gustavo Henrique Righi Ivahy. Direito Processual Penal. Tomo II. $2^{\mathrm{a}}$ ed. Rio de Janeiro: Elsevier, 2009.

BONFIM, Eugênio Moungenot. Curso de Processo Penal. $5^{a}$ ed. São Paulo: Saraiva, 2010.

BOSCHI, Marcus Vinicius. Código de Processo Penal Comentado. Porto Alegre: Livraria do advogado, 2008.

BRETAS, Adriano Sérgio Nunes. Estigma de pilatos: A desconstrução do mito do In dubio pro societate na pronúncia no rito do júri e a sua repercussão jurisprudencial. Curitiba: Juruá, 2010.

CAPEZ, Fernando. Curso de Processo Penal. 17ª ed. São Paulo: Saraiva, 2010.

CHOUKR, Fauzi Hassan. Código de Processo Penal. Comentários consolidados e crítica jurisprudencial. 4a ed Rio de Janeiro: Lumen Juris, 2010.

FILHO, Vicente Greco. Questões Polêmicas Sobre a Pronúncia, em "Tribunal do Júri: estudo sobre a mais democrática instituição jurídica brasileira"/ coordenação Rogério Lauria Tucci. São Paulo: Ed. Rev. dos Tribs., 1999, p. 118-9

LINS E SILVA, Evando. Artigo do Boletim IBCCRIM nº 100 Março/2001

LOPES JR., Aury. Direito processual penal e sua conformidade constitucional. Vol. II. Rio de Janeiro: 2009.

MONTEIRÓ, Cristina Líbano .Perigosidade de Inimputáveis e In Dubio Pro Reo". Coimbra: Universidade de Coimbra, Studia Juridica, Coimbra Editora, 1997, p. 47

MORAES, Maurício Zanoide de. Presunção de Inocência no Processo Penal Brasileiro: análise de sua estrutura normativa para a elaboração legislativa e para a decisão judicial. Rio de Janeiro: Lumen Juris, 2010. 
PEREIRA, Márcio Ferreira Rodrigues. Acusar ou não acusar? Eis a questão... . O "in dubio pro societate" como forma perversa de lidar com a dúvida no processo penal brasileiro.. Jus Navigandi, Teresina, ano 16, n. 2775, 5 fev. 2011. Disponível em: <http://jus.uol.com.br/revista/texto/18424>. Acesso em: 18 jul. 2011

PERES, César. Sentença de pronúncia: "in dubio pro societate"?. In: Âmbito Jurídico, Rio Grande, 22, 31/08/2005 [Internet]. Disponível em http://www.ambitojuridico.com.br/site/index.php?n_link=revista_artigos_leitura\&artigo_id

PINHO, Ana Cláudia Bastos de. In dubio pro societate $x$ processo penal garantista. Disponível em

http://alexandremoraisdarosa.blogspot.com/2009/06/puxada-de-orelhamerecida.html. Acesso em 15/07/2011.

PITOMBO, Sergio. Pronuncia e o in dubio pro societate. Disponível em http://www.sergio.pitombo.nom.br/files/word/in_dubio.doc. Acesso em 19/07/2011.

RANGEL, Paulo. Direito Processual Penal. $13^{\mathrm{a}}$ ed. Rio de Janeiro: Lumen Juris, 2007.

RUGGIERO, Roberto de. Instituições de Direito Civil; Introdução e Parte Geral", tradução Ary dos Santos, 3" ed., revista e adaptada por Antônio Chaves e Fábio Maria de Mattia, São Paulo: Saraiva, 1971, v. I.

TOURINHO FILHO, Fernando da Costa. Processo penal. vol. IV. $32^{a}$ ed. São Paulo: Saraiva, 2010. 